\title{
Ustvarjanje vključujoče šolske kulture: Usposabljanje po meri ravnateljev_ic
} Manja Veldin, Ana Mlekuž, Tina Vršnik Perše, Mateja Brejc, Svetlana Jurko

\section{Uvod}

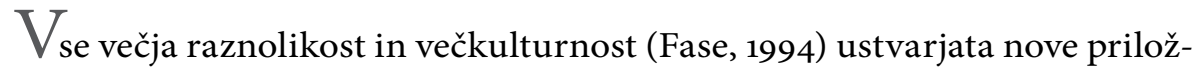
nosti in izzive za šole, kar ima velik vpliv na delo učiteljev_ic in ravnateljev_ic (Billot et al., 2007), saj se zaradi novih družbenih razmer pojavlja vse večja potreba po vključujočem izobraževanju (UNESCO, 2020). Cilj le-tega je obravnavanje in odzivanje na raznolikost potreb vseh učencev_k s povečanjem udeležbe $\mathrm{v}$ učenju, kulturah in skupnostih ter $\mathrm{z}$ zmanjševanjem izključenosti iz izobraževanja in znotraj izobraževanja (UNESCO, 2005). Deležniki znotraj šole lahko to dosežejo z ustvarjanjem vključujoče šolske kulture, ki zajema soglasje o vrednotah v šoli (npr. spoštovanje raznolikosti), zavezanost k zagotavljanju enakih možnosti vsem učencem_kam, visoko raven sodelovanja med šolskim osebjem, skupno reševanje problemov ter izbira vodij, ki podpirajo vključujoče vrednote in pri svojem vodenju spodbujajo sodelovanje (Dyson et al., 2004). Ustvarjanje vključujoče šolske kulture je torej eden najpomembnejših elementov vodenja v večkulturnih izobraževanih okoljih, saj spodbuja doseganje socialne pravičnosti znotraj šole (Foster, 1995).

$\mathrm{Na}$ to, kako se večkulturnost odraža na ravni šole, med drugim vplivajo ravnateljeva_ičina pedagoška vizija, cilji in načini vodenja (Keung in Rockinson-Szapkiw, 2013). Prav tako je vloga ravnatelja_ice na drugem mestu med vsemi dejavniki, povezanimi s šolo (prvi dejavnik je pouk $\mathrm{v}$ 
razredu), ki prispevajo k učenju v šoli (Bartoletti in Connelly, 2013). Ravnatelji_ce lahko neposredno vplivajo na profesionalno učenje učiteljev_ic, sodelovanje med učitelji_cami in sodelovanje učiteljev_ic pri odločanju, posredno pa lahko vplivajo na njihovo dobrobit ter na kakovost njihovih učnih praks (Thoonen et al., 2011). Prav tako so tudi učenci_ke uspešnejši v okoljih, kjer se učitelji_ce počutijo podprte in aktivno vključene v učenje (Johnston in Hayes, 2007). Pri ustvarjanju pozitivne in vključujoče šolske kulture je ključno tudi to, da se ravnateljevo_ičino vodenje šole osredotoča tako na učne dosežkov učencev_k kot na njihove individualne potrebe (Mulford, 2008). Z vsem tem lahko ravnatelji_ce podpirajo različnost učencev_k, vplivajo na zavzetost učiteljev_ic, organizacijsko kulturo, učinkovitost delovanja šole kot celote in ustvarjanje vključujoče šolske kulture (Ainscow, 2005).

Iz zgoraj zapisanega lahko sklepamo, da so ravnatelji_ce torej eden od ključnih akterjev pri ustvarjanju vključujoče šolske kulture. Ker je to kompleksen in zapleten proces, Dyson et al. (2002) predlagajo, da se ravnatelje_ ice ustrezno izbere in usposobi na področju vključujočih in nediskriminatornih praks in strategij, sodelovalnega vodenja ter razvoja šolskih vrednot, ki spodbujajo vključenost, multikulturalizem, ter sodelovanje med vsemi deležniki. Slovenija je sicer ena izmed držav v Evropski uniji, v kateri je za delovno mesto ravnatelja_ice obvezno opraviti posebno izobraževanje (Eurydice, 2015), vendar le-to redko vključuje teme, kot so raznolikost, nediskriminatorne prakse in strategije ali socialna pravičnost (Šola za ravnatelje, 2020), kljub temu da Slovenija postaja vse bolj raznolika družba (EMN, 2019).

Glavni namen tega prispevka je raziskati izkušnje in potrebe ravnateljev_ic slovenskih osnovnih in srednjih šol pri usposabljanju na področju ustvarjanja vključujoče šolske kulture, saj je za učinkovito strokovno usposabljanje odraslih nujno, da je le-to tesno povezano z izkušnjami in potrebami udeležencev, hkrati pa mora izhajati iz konteksta, v katerem udeleženci_ke delujejo (Cordingley et al., 2015; NSDC, 1995). S to raziskavo želimo torej zagotoviti ozadje za nadaljnji razvoj programov poklicnega razvoja, ki bi lahko podprli te specifične potrebe. V nadaljevanju predstavljamo del izsledkov preliminarne raziskave v okviru projekta »HEAD: Za opolnomočenje ravnateljic in ravnateljev pri oblikovanju vključujoče šolske kulture«, katerega glavni cilj je razvoj izobraževanja za ravnatelje_ice osnovnih in srednjih šol na področju inkluzivnega izobraževanja. Raziska- 
va je bila opravljena tudi v Republiki Makedoniji in na Hrvaškem, vendar za namene te študije predstavljamo le slovenske podatke.

\section{Metoda}

\section{Udeleženci_ke}

V raziskavi je sodelovalo 107 ravnateljev_ic iz slovenskih osnovnih in srednjih šol (71 \% na OŠ, $22 \%$ na SŠ, 7 \% neodgovorjeno). Priložnostni vzorec večinoma sestavljajo ravnateljice (6o \%; $34 \%$ ravnateljev; $6 \%$ neodgovorjeno), z izobrazbo iz družboslovnih ved (51,4 \%, 35,5 \% naravoslovne vede, 8,4 $\%$ drugo, 4,7 \% neodgovorjeno) ter v povprečju 27,15 let delovnih izkušenj v šolskem okolju, od tega 10,49 let na mestu ravnatelja_ice.

\section{Pripomočki in postopek}

Za namene projekta HEAD, smo v konzorciju razvile vprašalnik, s katerim smo želele ugotoviti, kakšne so splošne potrebe ravnateljev_ic po usposabljanju za ustvarjanje vključujoče šolske kulture na njihovih šolah. V raziskavi smo uporabile nekatere uveljavljene mere, ki smo jih prilagodile glede na specifične cilje projekta in vzorec udeležencev. Udeleženci raziskave so marca 2020 preko Šole za ravnatelje prejeli povezavo do spletnega vprašalnika (portal $1 \mathrm{ka}$ ).

Vprašalnik je zajemal štiri vsebinske sklope.

Demografske podatke, kjer nas je zanimalo osebno in strokovno ozadje ravnateljev_ic ter specifike šol, ki jih vodijo.

Predhodno strokovno usposabljanje na področju inkluzivne šolske kulture, kjer nas je zanimalo, kakšnih strokovnih usposabljanj se ravnatelji_ ce udeležujejo ter ali je katero od njih $\mathrm{v}$ zadnjih petih letih spodbujalo razvoj inkluzivne šolske kulture. Vprašanji sta bili osnovani na vprašanjih raziskave TALIS 2018 o profesionalnem razvoju učiteljev_ic in ravnateljev_ ic (OECD, 2018a, 2018b) ter prilagojeni za področje vključujoče šolske kulture. Udeleženci_ke so odgovorili na vprašanje, ali so se v zadnjih petih letih udeležili usposabljanja, ki je nagovarjalo teme ustvarjanja vključujoče šolske kulture. Sledilo je vprašanje o vrstah izobraževanj, ki so se jih udeležili_e, kjer so lahko izbrali_e med navedenimi opcijami. Prav tako so lahko dopisali_e druge vrste izobraževanja, ki niso bile navedene med podanimi možnostmi.

Značilnosti strokovnega usposabljanja, ki so imele najbolj pozitiven doprinos $k$ vodenju šole, kjer nas je zanimalo, katere značilnosti usposab- 
ljanj, ki so se jih ravnatelji_ce udeležili_e, so imele največ pozitivnega vpliva na ravnateljevo_ičino vodenje v zadnjih 12 mesecih. Vprašanje je bilo, tako kot predhodno, osnovano (in prilagojeno našim ciljem) na vprašanjih raziskave TALIS 2018 (OECD, 2018a, 2018b). Udeleženci_ke so med devetimi postavkami izbrali_e tiste, ki so jih prepoznali_e kot značilnosti $\mathrm{z}$ najbolj pozitivnim vplivom na njihovo vodenju šole. Prav tako so lahko dopisali_e značilnosti, ki niso bile opredeljene med možnimi odgovori. Na uporabljenem vzorcu koeficient zanesljivosti dosega zadovoljivo vrednost (Cronbach $\alpha=0,67$ ).

Zaznane potrebe po usposabljanju na področjih, povezanih $z$ ustvarjanjem vključujoče šolske kulture, kjer nas je zanimalo, katera specifična področja znotraj ustvarjanja vključujoče šolske kulture bi ravnatelji_ce želeli_e nadgraditi in kje se čutijo v svoji praksi bolj kompetentni_e. Lestvica je bila razvita na osnovi Indeksa inkluzivnosti (Booth in Ainscow, 2002) in prilagojena kontekstom in ciljem projekta. Obsegala je potrebe po usposabljanju na treh širših področjih: (1) ustvarjanje vključujoče kulture (npr. vzpostavljanje vključujočih vrednot), (2) oblikovanje vključujočih politik (npr. organizacija podpore za raznolikost) in (3) razvijanje vključujočih praks (npr. organiziranje učenja). Prav tako je lestvica vsebovala potrebe po dodatnem znanju in razumevanju področja vključujoče šolske kulture ter sposobnosti za ozaveščanje svojih (ne)vključujočih praks in praks ostalih deležnikov, vpletenih v šolski sitem. Ravnatelji_ce so na 4-stopnjski Likertovi lestvici (1-Sploh ne potrebujem: 4-Nujno potrebujem) označili_e, v kolikšni meri trenutno potrebujejo strokovno usposabljanje za vsako od naštetih področij (18 postavk). Na uporabljenem vzorcu koeficient zanesljivosti dosega odlično vrednost (Cronbach $\alpha=0,93$ ).

\section{Analize}

Statistične analize (testi zanesljivosti, deskriptivne statistike, $\chi^{2}$ test, t-testi) smo naredile s programom IBM SPSS Statistics 27. Za primerjavo neodvisnih vzorcev smo $\mathrm{v}$ primerih intervalnih spremenljivk uporabile t-test, saj so se spremenljivke porazdeljevale po normalni distribuciji. Pri primerjavi neodvisnih vzorcev $\mathrm{v}$ primeru nominalne spremenljivke smo uporabile $\chi^{2}$ test. Vse statistične hipoteze smo testirale pri 5-odstotni ravni alfa napake. Grafi so za lažji uvid v rezultate prikazani od največjega deleža odgovorov do najmanjšega. Tabela je preurejena na način, da si področja znotraj ustvarjanja vključujoče šolske kulture sledijo od zgoraj navzdol (od najbolj 
pereče potrebe po izobraževanju do najmanj nujne), glede na povprečen odgovor udeležencev na postavko.

\section{Rezultati}

V prvem delu rezultatov predstavljamo, kakšno je bilo predhodno strokovno usposabljanje udeležencev na področju vključujoče šolske kulture v zadnjih petih letih. Nadaljujemo s prepoznanimi značilnostmi strokovnega usposabljanja, ki so imele najbolj pozitiven doprinos k vodenju šol naših udeležencev. Rezultate zaokrožimo s predstavitvijo odgovorov o zaznanih potrebah po dodatnem usposabljanju na področju ustvarjanja vključujoče šolske kulture.

Strokovno usposabljanje znotraj šole

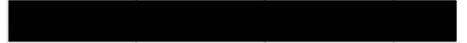
0,70

Strokovno usposabljanje v organizaciji institucije na državni ravni

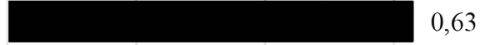

Strokovno usposabljanje znotraj projekta

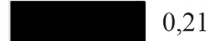

0,21

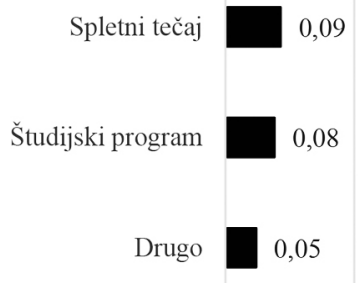

$\begin{array}{llllll}0,00 & 0,20 & 0,40 & 0,60 & 0,80 & 1,00\end{array}$

Slika I: Delež ravnateljev_ic, udeleženih na raznolikih vrstah strokovnega izobraževanja na področju vključujoče šolske kulture

Rezultati študije kažejo, da med odgovori ravnateljev_ic srednjih $(M=$ $0,77, S D=0,43)$ in osnovnih šol $(M=0,86, S D=0,34)$ ni značilnih razlik v poročanju o predhodnem strokovnemu usposabljanju povezanim $\mathrm{z}$ vključujočo šolsko kulturo $\left(\chi^{2}(1)=1.26, p=.26\right)$. Velika večina ravnateljev_ic $(83,2 \%)$ je v zadnjih 5-ih letih sodelovala v usposabljanjih, ki so nagovarjala razvoj vključujoče šolske kulture $(M=1,74$ različnih usposabljanj, $S D=$ o,83). Na Sliki 1 lahko razberemo, da so usposabljanja, na katerih so sodelo- 
vali udeleženci, največkrat potekala znotraj šole oziroma bila organizirana znotraj institucije na državni ravni. Manj kot $10 \%$ ravnateljev_ic je poročalo o sodelovanju na usposabljanju preko spletnega tečaja in sodelovanju na študijskem programu. Kot druge vrste izobraževanja so udeleženci navajali samoizobraževanje ter sodelovanje na tečaju v tujini.

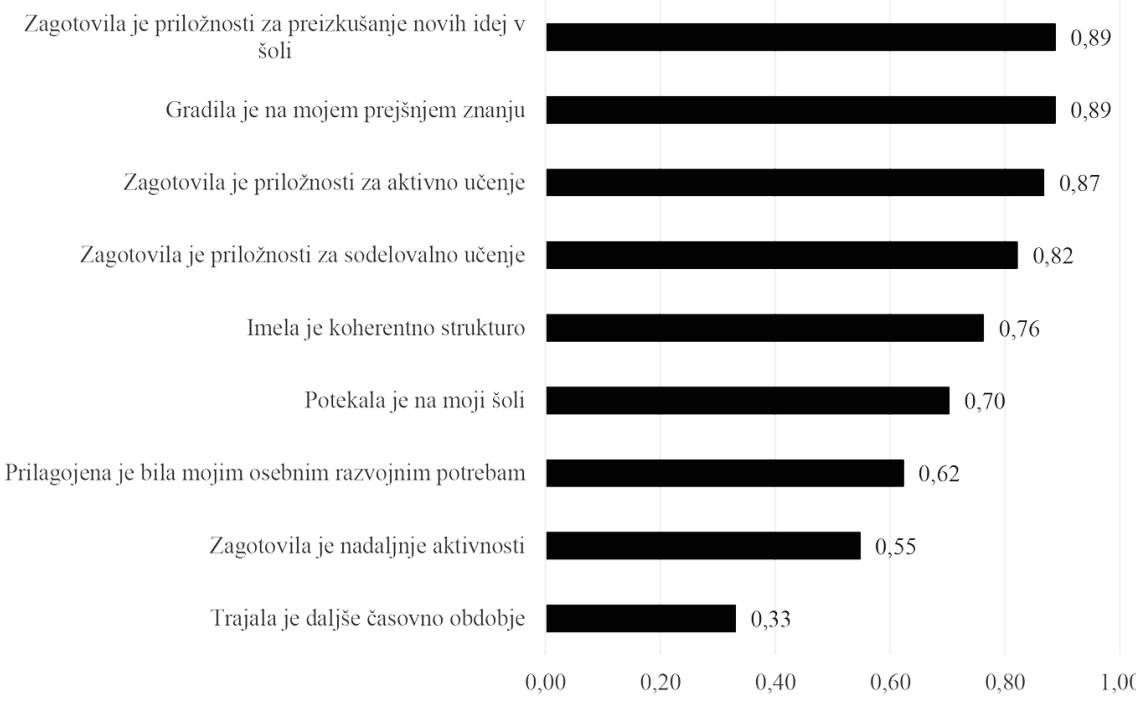

Slika 2: Deležravnateljev_ic, ki je pripisal izbranim značilnostim strokovnega usposabljanja pozitiven doprinos $k$ njihovim praksam vodenja šole

Prepoznane značilnosti strokovnih usposabljanj, ki so imele najbolj pozitiven doprinos $\mathrm{k}$ vodenju šole $\mathrm{v}$ zadnjem letu, so razvidne na Sliki 2. Izkazalo se je, da je največ ravnateljev_ic ocenilo, da so vodila v izboljšanje njihove prakse vodenja šole tista usposabljanja, ki so zagotovila priložnosti za preizkušanje novih idej $v$ šoli ter izgradnjo novih vsebin na predznanju udeležencev. Prav tako je velika večina ravnateljev_ic pri svojem delu prepoznala pozitiven vpliv tistih usposabljanj, ki so zagotovila priložnosti za aktivno in sodelovalno učenje ter da je usposabljanje imelo koherentno strukturo. Najmanjši odstotek ravnateljev_ic je ocenil, da je daljše trajanje usposabljanja pozitivno prispevalo k spremembi njihovih praks. Noben_a ravnatelj_ica ni prepoznal_a dodatnih značilnosti, zato le-te niso vključene v graf. $V$ povprečju so ravnatelji_ce za večino naštetih značilnosti odgovorili_e, da pozitivno vplivajo na njihove prakse $(M=6,40, S D=1,95)$. Pomembnost prisotnosti večine naštetih značilnosti usposabljanja se kaže 
tudi $\mathrm{v}$ tem, da se količina prepoznanih karakteristik med odgovori ravnateljev_ic osnovnih $(M=6,49, S D=1,88)$ in srednjih šol $(M=5,91, S D=2,30)$ ne razlikuje statistično pomembno $(\mathrm{t}(96)=1.23, \mathrm{p}=.22)$.

Ne glede na predhodna usposabljanja, ravnatelji_ce še vedno izražajo veliko potreb po usposabljanju na področju ustvarjanja vključujoče šolske kulture $(M=2,66 ; S D=0,50)$. Tudi v izraženih potrebah po usposabljanju preko vseh področij ustvarjanja vključujoče šolske klime se ravnatelji_ce osnovnih $(M=2,66$; $S D=0,51)$ in srednjih šol $(M=2,66$; $S D=0,48)$ ne razlikujejo statistično pomembno $(t(97)=0.01, p=.99)$.

V Tabeli 2 lahko razberemo, katera specifična področja znotraj ustvarjanja vključujoče šolske kulture bi ravnatelji_ce želeli_e nadgraditi in kje se čutijo $\mathrm{v}$ svoji praksi bolj kompetentni. V tabeli so prikazani deleži ravnateljev_ic, ki so izbrali določen odgovor (od 1 - »Sploh ne potrebujem « do 4 - »Nujno potrebujem«) ter povprečen odgovor na postavko preko vseh udeležencev raziskave (in pripadajoča standardna deviacija). Kot najbolj nujne teme, kjer bi potrebovali_e dodatno znanje, ravnatelji_ce izpostavljajo pripravo šolskega osebja na primerno odzivanje na različnost učencev, razvijanje in udejanjenje jasnih pravil za osebje, ki bi podpiralo razvoj vključujoče šolske kulture, spodbujanje vključujočih učnih praks učiteljev, razvijanje in spodbujanje sodelovanja med učenci, učitelji in drugimi deležniki ter zbiranje in upravljanje finančnih in človeških virov za podporo vključujoči šolski kulturi. Najmanj potreb izražajo pri spodbujanju ustvarjanja vključujočega fizičnega okolja ter zavedanja lastnih (ne)inkluzivnih praks in prepričanj o raznolikosti in inkluziji. Če združimo tiste udeležence_ke, ki čutijo večjo potrebno po usposabljanju na tem področju (odgovora 3 in $4 \mathrm{oz}$. tiste, ki "potrebujejo usposabljanje v večji meri« in tiste, ki "potrebujejo usposabljanje nujno«), se delež le-teh giblje med 34,6 \% in 72,9\% preko vseh izbranih področij $(M=58,05 \%)$. Tako tudi ustvarjanje vključujočega fizičnega okolja, ki se sicer uvršča med manj nujne teme, postane relativno pomembna tema usposabljanja za kar $49,5 \%$ ravnateljev_ic. Hkrati tudi redkost izbire odgovora »Sploh ne potrebujem « (o - 16,8 \%; $M=4,4$ $\%$ ), nakazuje, da je prisotna potreba po dodatnem usposabljanju. Prav tako je $14,1 \%(8,4 \%-28 \%)$ ravnateljev_ic izrazilo nujno potrebo (odgovor 4$)$ po dodatnem usposabljanju preko vseh področij. 
Tabela 2: Potrebe po strokovnem usposabljanju za ustvarjanje vključujoče šolske kulture glede na zastopanost posameznega odgovora v vzorcu in povprečen odgovor na postavko

\begin{tabular}{|c|c|c|c|c|c|c|}
\hline $\begin{array}{l}\text { Področja potreb po } \\
\text { strokovnem usposa- } \\
\text { bljanju }\end{array}$ & $\begin{array}{l}\text { Sploh ne } \\
\text { potrebujem }\end{array}$ & $\begin{array}{l}\text { Potrebu- } \\
\text { jem v manjši } \\
\text { meri }\end{array}$ & $\begin{array}{l}\text { Potrebujem } \\
\text { v večji meri }\end{array}$ & $\begin{array}{c}\text { Nujno } \\
\text { potrebujem }\end{array}$ & M & $\mathrm{SD}$ \\
\hline $\begin{array}{l}\text { Priprava šolskega ose- } \\
\text { bja na primerno od- } \\
\text { zivanje na raznolike } \\
\text { učence }\end{array}$ & 1,9 & 25,2 & 44,9 & 28,0 & 2,99 & 0,78 \\
\hline $\begin{array}{l}\text { Razvijanje in udeja- } \\
\text { njenje jasnih pravil } \\
\text { za osebje, ki podpira- } \\
\text { jo IŠK }\end{array}$ & 0,0 & 29,0 & 50,5 & 20,6 & 2,92 & 0,70 \\
\hline $\begin{array}{l}\text { Spodbujanje inkluziv- } \\
\text { nih učnih praks }\end{array}$ & 0,0 & 29,0 & 53,3 & 17,8 & 2,89 & 0,68 \\
\hline $\begin{array}{l}\text { Razvijanje in spodbu- } \\
\text { janje sodelovanja (uči- } \\
\text { telji, učenci idr.) }\end{array}$ & 2,8 & 29,9 & 48,6 & 18,7 & 2,83 & 0,76 \\
\hline $\begin{array}{l}\text { Zbiranje in upravljanje } \\
\text { finančnih in človeških } \\
\text { virov za podporo IŠK }\end{array}$ & 2,8 & 32,7 & 43,9 & 20,6 & 2,82 & 0,79 \\
\hline $\begin{array}{l}\text { Evalvacija in uporaba } \\
\text { podatkov za izboljša- } \\
\text { nje IŠK }\end{array}$ & 1,9 & 28,0 & 58,9 & 11,2 & 2,79 & 0,65 \\
\hline $\begin{array}{l}\text { Izvajanje razvojne- } \\
\text { ga načrta šole za pod- } \\
\text { pro IŠK }\end{array}$ & 9 & 34,6 & 51,4 & 13,1 & 2,77 & 0,68 \\
\hline $\begin{array}{l}\text { Izvajanje šolskega uč- } \\
\text { nega načrta za podpo- } \\
\text { ro IŠK }\end{array}$ & 2,8 & 31,8 & 52,3 & 12,1 & 2,75 & 0,70 \\
\hline $\begin{array}{l}\text { Izvajanje uspešnih } \\
\text { strategij proti nasilju }\end{array}$ & 3,7 & 36,4 & 43,9 & 15,9 & 2,72 & 0,77 \\
\hline $\begin{array}{l}\text { Organiziranje in } \\
\text { usklajevanje podpore } \\
\text { za različnost }\end{array}$ & 1,9 & 38,3 & 50,5 & 8,4 & 2,66 & 0,66 \\
\hline $\begin{array}{l}\text { Razvijanje in spodbu- } \\
\text { janje sodelovanja (star- } \\
\text { ši, lokalna skupnost) }\end{array}$ & 3,7 & 41,1 & 43,9 & 11,2 & 2,63 & 0,73 \\
\hline $\begin{array}{l}\text { Razvoj šolskih politik, } \\
\text { ki so v skladu s princi- } \\
\text { pi inkluzije }\end{array}$ & 5,6 & 41,1 & 42,1 & 11,2 & 2,59 & 0,76 \\
\hline $\begin{array}{l}\text { Spodbujanje aktivnega } \\
\text { sodelovanja staršev }\end{array}$ & 4,7 & 43,9 & 40,2 & 11,2 & 2,58 & 0,75 \\
\hline $\begin{array}{l}\text { Spodbujanje šolskih } \\
\text { vrednot, ki podpirajo } \\
\text { inkluzijo }\end{array}$ & 3,7 & 50,5 & 30,8 & 15,0 & 2,57 & 0,79 \\
\hline $\begin{array}{l}\text { Znanje in razumeva- } \\
\text { nje (IŠK) }\end{array}$ & 3,7 & 46,7 & 41,1 & 8,4 & 2,54 & 0,70 \\
\hline $\begin{array}{l}\text { Ustvarjanje inkluziv- } \\
\text { nega okolja }\end{array}$ & 12,1 & 38,3 & 36,4 & 13,1 & 2,50 & 0,87 \\
\hline
\end{tabular}




\begin{tabular}{lcccccc}
$\begin{array}{c}\text { Področja potreb po } \\
\text { strokovnem usposa- } \\
\text { bljanju }\end{array}$ & $\begin{array}{c}\text { Sploh ne } \\
\text { potrebujem }\end{array}$ & $\begin{array}{c}\text { Potrebu- } \\
\text { jem v manjši } \\
\text { meri }\end{array}$ & $\begin{array}{c}\text { Potrebujem } \\
\text { v večji meri }\end{array}$ & $\begin{array}{c}\text { Nujno } \\
\text { potrebujem }\end{array}$ & M & SD \\
$\begin{array}{l}\text { Zavedanje lastnih pre- } \\
\text { pričanj o raznolikosti } \\
\text { in inkluziji }\end{array}$ & 10,3 & 46,7 & 31,8 & 9,3 & 2,41 & 0,80 \\
\hline $\begin{array}{l}\text { Zavedanje svojih ne- } \\
\text {-inkluzivnih praks }\end{array}$ & 16,8 & 48,6 & 26,2 & 8,4 & 2,26 & 0,84 \\
\hline
\end{tabular}

Opombe: IŠK = inkluzivna šolska kultura.

\section{Diskusija}

Pedagoška vizija, cilji in prakse vodenja ravnateljev_ic vplivajo na to, kako se na šolski ravni izraža raznolikost in vključujoča šolska kultura (Hajisoteriou in Angelides, 2013; Keung in Rockinson-Szapkiw, 2013; McGlynn, 2008), katere razvoj je kompleksen proces, ravnatelje_ice pa je za to potrebno ustrezno usposobiti (Davila, 2009; Dyson et al., 2004; Young et al., 2010), še posebej na področju vključujočih in nediskriminatornih praks, strategij razvoja vključujočih vrednot, sodelovanja itd. Učinkovit progam strokovnega usposabljanja se mora povezovati z izkušnjami in potrebami ravnateljev_ic in kontekstom, v katerem udeleženci_ke delujejo (npr. Cordingley et al., 2015). Namen naše študije je bil raziskati predhodne izkušnje z usposabljanjem ter potrebe ravnateljev_ic slovenskih osnovnih in srednjih šol po usposabljanju na področju vključujoče šolske kulture in tako zagotoviti ozadje za nadaljnji razvoj programov poklicnega razvoja, ki bi lahko te specifične potrebe podprli.

Rezultati naše študije kažejo, da je večina slovenskih ravnateljev_ic že sodelovala $\mathrm{v}$ usposabljanju(ih) na področju ustvarjanja vključujoče šolske kulture. Na podlagi tega bi lahko sklepali, da je večina slovenskih ravnateljev_ic opremljenih z znanji in kompetencami, potrebnimi za vzpostavljanje in vzdrževanje vključujoče šolske kulture, vendar temu ni tako, saj več kot polovica istih ravnateljev_ic izraža potrebo po dodatnem izobraževanju preko vseh področij »v večji meri« oziroma "nujno« (več v Tabeli 2). Do podobnih zaključkov so prišli tudi drugi raziskovalci (npr. Bai in Martin, 2015; Bustamante et al., 2009). Najpogosteje so ravnatelji_ce poročali_e o sodelovanju na usposabljanju znotraj šole ter na instituciji na državni ravni. Druge vrste usposabljanja so bile veliko redkejše. Na voljo je na primer veliko brezplačnih spletnih usposabljanj in študijskih programov (npr. na spletni strani Class central, o razumevanju raznolikost in inkluzije), ki se jih naši_e ravnatelji_ce skorajda ne poslužujejo oziroma se jih niso poslu- 
ževali_e v času študije, kar se je lahko oziroma se bo verjetno spremenilo zaradi trenutnih omejitev povezanih z epidemijo.

Rezultati naše študije nakazujejo, da je večina naštetih značilnosti usposabljanj (npr. da le-to zagotavlja priložnosti za sodelovalno učenje) pomembna za doprinos k delu ravnatelja_ice, kar kaže na to, da je za učinkovito usposabljanje potrebno prepletati in vključevati raznolike načine dela in se prilagajati udeležencem in njihovim osebnim ter profesionalnim kontekstom. Slednje izpostavljajo tudi drugi avtorji (npr. Cordingley et al., 2015). Ravnatelji_ce kot najpomembnejše značilnosti izpostavljajo zagotavljanje priložnosti za preizkušanje novih idej v šoli, izgradnjo novih vsebin na njihovem predznanju, zagotavljanje priložnosti za aktivno in sodelovalno učenje ter koherentno strukturo usposabljanja. Podobne značilnosti učinkovitih usposabljanj navajajo tudi drugi avtorji (npr. Cordingley et al., 2015; OECD, 2019). Najmanjši doprinos ravnatelji_ce pripisujejo trajanju usposabljanja, kar pomeni, da učinkovito usposabljanje ni nujno tudi dolgotrajno. Slednje podpirajo tudi drugi avtorji (Timperley et al., 2007), ki trdijo, da je pomembnejša pogostost stika in intenzivnost (npr. celodnevne delavnice). Prav tako je pomembnost dolžine treninga v obratnem sorazmerju s širino obravnavane tematike (za ožje področje je potrebno manj časa).

Nadalje, naši rezultati kažejo, da ravnatelji_ce osnovnih in srednjih šol poročajo o enakih potrebah po izobraževanju o temah vključujoče šolske kulture, iz česar sklepamo, da bi lahko sodelovali na enakem usposabljanju oziroma usposabljanja ne bi bilo potrebno prilagajati izobraževalni ravni. Na podlagi ugotovitev študije bi za način dela, znotraj novonastalih usposabljanj, priporočali preplet vseh prepoznanih značilnosti (več na Sliki 2), s poudarkom na zagotavljanju možnosti za preizkušanje idej v praksi, vpeljevanjem vsebin, temelječih na predznanju udeležencev, ter zagotavljanju priložnosti za aktivno in sodelovalno učenje. Kot najbolj nujne teme novega usposabljanja (več v Tabeli 2) bi bile prepoznane priprava šolskega osebja na primerno odzivanje na različnost učencev, razvijanje in udejanjenje jasnih pravil za osebje ter spodbujanje vključujočih učnih praks učiteljev. Podobne potrebe navajajo tudi drugi avtorji (Miller et al., 2016), ki poročajo o visokih učinkih strokovnega usposabljanja ravnateljev_ic, kjer nakljub povišani učinkovitosti, znanju in spremembi stališč ravnateljev_ic, dodatno izpostavljajo nujo po nagovarjanju neposrednega dela ravnatelja_ce $z$ učitelji_cami. Prav slednje naj bi bila ena od pomembnejših značilnosti ravnate- 
ljevega_ičinega dela, izgradnja zaupanja v odnosih z učitelji, ki naj bi vodilo v sporazumno sodelovanje (Brewster in Railsback, 2003; Modoono, 2017).

Naši udeleženci nadalje navajajo visoke potrebe po usposabljanju na področjih evalvacije in uporabe podatkov za izboljšanje vključujoče šolske kulture, razvijanje in spodbujanje sodelovanja med učenci, učitelji in drugimi deležniki ter zbiranje in upravljanje finančnih in človeških virov za podporo vključujoče šolske kulture. Pomembnost naštetih tem poudarjajo tudi tuji avtorji, saj naj bi strateško usklajevanje človeških in finančnih virov vodilo $\mathrm{v}$ izboljšanje prakse poučevanja in učenja, spremljanje in evalvacija praks pa v zagotavljanje ustreznega usposabljanja (Day in Sammons, 2013) in, nenazadnje, sodelovanje $\mathrm{z}$ različnimi deležniki $\mathrm{v}$ bolj pozitivno klimo (Price, 2012).

Slovenski_e ravnatelji_ce se počutijo najbolj kompetentni_e pri spodbujanju vključujočega fizičnega okolja ter pri zavedanju lastnih (ne)vključujočih praks in prepričanj o raznolikosti in inkluziji. Prav vrednote in stališča ravnateljev_ic naj bi pomembno prispevali k vzpostavljanju vključujoče šolske kulture (Adalbjarnardottir in Runarsdottir, 2006; Angelides, 2012), zato bi bilo potrebno v našem vzorcu podrobneje raziskati, kakšna so dejanska prepričanja slovenskih ravnateljev_ic, saj tudi UNESCO (2013) kot eno od ovir za napredek inkluzivnosti izobraževanja navaja pomanjkanje spoštovanja raznolikosti ter negativna stališča do kulturnih, družbenih, ekonomskih razlik in razlik med spoli.

Zaradi relativno majhnega vzorca udeležencev, le-ti zastopajo šestino vseh slovenskih ravnateljev_ic, je pri posploševanju naših rezultatov potrebna previdnost. Prav tako je bil izbor udeležencev priložnostni in nenaključen, saj so se za sodelovanje v naši raziskavi posamezniki odločili samostojno, kar pomeni, da jih tema verjetno bolj zanima, so bolj motivirani in imajo večje potrebe po takem usposabljanju. Nadalje je potrebno izpostaviti, da je v našem vzorcu izrazito manj ravnateljev_ic iz srednjih šol, kot iz osnovnih, kar prav tako otežuje posplošitev rezultatov. Naše ugotovitve sicer kažejo, da se potrebe po izobraževanju ne razlikujejo glede na izobraževalno raven, a hkrati ne dajejo vpogleda $\mathrm{v}$ dejansko stanje, $\mathrm{v}$ znanje in prakse ravnateljev_ic in razlike, ki bi lahko bile vidne na isti ravni med različnimi vrstami šol (npr. med gimnazijami in strokovnimi šolami). Prav tako bi bilo smiselno raziskati, kakšne so te razlike med različnimi srednjimi šolami in drugimi izobraževalnimi institucijami, ki naj bi zagotavljale vključujočo kulturo. Nenazadnje bi bilo potrebno v merski instrument vključiti tudi druge metode pridobivanja podatkov (npr. opazovanje) in se 
ne zanašati le na samoocene udeležencev, ki lahko vodijo v podcenjevanje potreb po usposabljanju oziroma $\mathrm{v}$ precenjevanje lastnih praks in seveda tudi obratno. Naše ugotovitve bi lahko vodile v širšo raziskavo, predvsem pa v spremenjen način priprave novih usposabljanj, kjer bi izvajalci vnaprej preverili, katera znanja in način dela so potrebni, zaželeni in najbolj učinkoviti pri določenih udeležencih ter prilagodili usposabljanje glede na kontekst, v katerem udeleženci delajo.

\section{Literatura}

Adalbjarnardottir, Sigrun in Eyrun Maria Runarsdottir. "A leader's experiences of intercultural education in an elementary school: Changes and challenges." Theory into Practice 45, no. 2 (2006): 177-186.

Ainscow, Mel. »Developing inclusive education systems: What are the levers for change? « Journal of Educational Change 6 (2005): 109-24.

Angelides, Panayiotis. "Forms of leadership that promote inclusive education in Cypriot schools" Educational Management Administration in Leadership 40, no. 1 (2012): 21-36.

Bai, Haiyan in Martin, Suzanne. M. »Assessing the needs of training on inclusive education for public school administrators « International Journal of Inclusive Education 19, no. 12 (2015): 1229-1243.

Bartoletti, Robert James in Gail Connelly. Leadership matters: What the research says about the importance of principal leadership. National Association of Elementary School Principals, 2013.

Billot, James, J. Tim Goddard in Neil Cranston »How principals manage ethnocultural diversity: Learnings from three countries « International Studies in Educational Administration 35, no. 2 (2007): 3-19.

Booth, Tony in Mel Ainscow, M. Index for Inclusion: Developing learning and participation in schools. Bristol: Centre for Studies on Inclusive Education (CSIE), 2002.

Brewster, Cori in Jennifer Railsback. Building trusting relationships for school improvement: Implications for principals and teachers. Portland, OR: Northwest Regional Educational Laboratory, 2003.

Bustamante, Rebecca M., Judith A. Nelson in Anthony J. Onwuegbuzie. »Assessing schoolwide cultural competence: Implications for school leadership preparation « Educational administration quarterly 45, no. 5 (2009):793-827. 
Class Central. »Free Online Course: Understanding Diversity and Inclusion from FutureLearn«. https://www.classcentral.com/course/diversity-inclusion-awareness-9883.

Cordingley, Philippa, Steve Higgins, Toby Greany, N. Buckler, D. Coles-Jordan, B. Crisp, L. Saunders, in Robert Coe. Developing great teaching: lessons from the international reviews into effective professional development. Project Report. London: Teacher Development Trust, 2015.

Davila, Gilbert. »Preparing School Principals for a Diverse and Changing World « Educational Considerations 37, no. 1 (2009): 53-55.

Day, Christopher in Pamela Sammons. Successful leadership: A review of the international literature. Reading, England: CfBT Education Trust, 2013. Dostopno na https://files.eric.ed.gov/fulltext/ED546806.pdf.

Dyson, Alan, Andy Howes in Barbara Roberts. A systematic review of the effectiveness of school-level actions for promoting participation by all students. London: Institute of Education, 2002.

Dyson, Alan, Peter Farrell, Filiz Polat, Graeme Hutcheson in Frances Gallannaugh. Inclusion and pupil achievement. Research Report No. 578. London: Department for Education and Skills, 2004.

EMN. »Poročilo o delu Urada za migracije za leto 2019«. Zadnjič spremenjeno leta 2019. http://emm.si/wp-content/uploads/Porocilo_2018_SLO.pdf.

Eurydice. Key data on teachers and school leaders in Europe. Eurydice, 2015. Dostopno na https://op.europa.eu/en/publication-detail/-/publication/17ad39ad-dcad-4155-8650-5c63922f8894.

Fase, Willem. Ethnic divisions in Western European education (Vol. 1). Waxmann, 1994.

Foster, Michele. „African American teachers and culturally relevant pedagogy«. V Handbook of Research on Multicultural Education, uredila J. A. Banks in C. A. McGee Banks, 570-581. New York: Macmillan, 1995.

Hajisoteriou, Christina in Panayiotis Angelides. „Facing the 'challenge' School leadership in intercultural schools « Educational Management Administration in Leadership 42, no. 4_suppl (2013): 65-82.

Johnston, Ken in Debra Hayes. »Supporting student success at school through teacher professional learning: The pedagogy of disrupting the default modes of schooling « International Journal of Inclusive Education 11, no. 3 (2007): 371-381.

Keung, Emerson K., in Amanda J. Rockinson-Szapkiw. "The relationship between transformational leadership and cultural intelligence: A study 
of international school leaders « Journal of Educational Administration 51, no. 6 (2013): 836-854.

McGlynn, Claire. »Leading integrated schools: A study of the multicultural perspectives of Northern Irish principals « Journal of Peace Education 5, no. 1 (2008): 3-16.

Miller, Robert James, Roger D. Goddard, Minjung Kim, Robin Jacob, Yvonne Goddard in Patricia Schroeder. „Can professional development improve school leadership? Results from a randomized control trial assessing the impact of McREL's balanced leadership program on principals in rural Michigan schools« Educational Administration Quarterly 52, no. 4 (2016): 531-566.

Modoono, Jane. »The trust factor« Educational Leadership 74, no. 8 (2017): 1420.

Mulford, Bill. The leadership challenge: Improving learning in schools. Victoria: ACER Press, 2008. Dostopno na https://research.acer.edu.au/cgi/viewcontent.cgi? article $=1000$ incontext $=$ aer.

NSDC - National Staff Development Council. Standards for staff development. Oxford, OH: Author, 1995.

OECD. »Teaching and Learning International Survey (TALIS): Principal Questionnaire«, 2018b. Dostopno na http://www.oecd.org/education/school/ TALIS-2018-MS-Principal-Questionnaire-ENG.pdf.

OECD. »Teaching and Learning International Survey (TALIS): Teacher Questionnaire«, 2018a. Dostopno na http://www.oecd.org/education/school/TALIS-2018-MS-Teacher-Questionnaire-ENG.pdf.

OECD. TALIS 2018 Results (Volume I): Teachers and School Leaders as Lifelong Learners. Paris: OECD Publishing, 2019. Dostopno na https://www.oecd. org/education/talis/talis-2018-results-volume-i-1dobc92a-en.htm.

Price, Heather E. »Principal-teacher interactions: How affective relationships shape principal and teacher attitudes « Educational Administration Quarterly 48, no. 1 (2012): 39-85.

Šola za ravnatelje. »Šola za ravnatelje« 2020. Dostopno na http://solazaravnatelje.si/.

Thoonen, Erik E. J., Peter J. C. Sleegers in Frans J. Oort. »How to improve teaching practices: the role of teacher motivation, organizational factors, and leadership practices Educational Administration Quarterly 47 (2011): 496-536. 
Timperley, Helen, Aaron Wilson, H. Barrar in I. Fung. Teacher professional learning and development. Best evidence synthesis iteration (BES). Wellington, New Zealand: Ministry of Education, 2007. Dostopno na http://www. oecd.org/education/school/48727127.pdf.

UNESCO. "Inclusive Education. Education Sector Technical Notes", 2013. Dostopno na https://unesdoc.unesco.org/ark:/48223/pfoooo222124.

UNESCO. "Towards inclusion in education: Status, trends and challenges. The UNESCO Salamanca Statement 25 years on «, 2020. Dostopno na https:// www.gcedclearinghouse.org/sites/default/files/resources/200647eng.pdf.

UNESCO. Guidelines for inclusion: Ensuring Access to Education for All. Paris: UNESCO, 2005.

Young, Billy L., Jean Madsen in Mary Ann Young. »Implementing diversity plans: Principals' perception of their ability to address diversity in their schools« NASSP Bulletin 94, no. 2 (2010): 135-157. 